\title{
GAMBARAN DENYUT NADI PADA PEMAIN MUSIK DI TOMS YAMAHA MUSIC SCHOOL MANADO
}

\author{
${ }^{1}$ Jesica Sondakh \\ ${ }^{2}$ Nancy Engka \\ ${ }^{2}$ Siantan Supit
}

\author{
${ }^{1}$ Kandidat Skripsi Fakultas Kedokteran Universitas Sam Ratulangi Manado \\ ${ }^{2}$ Dosen Bagian Fisiologi Fakultas Kedokteran Universitas Sam Ratulangi Manado \\ Email: shicilya_sondakh@yahoo.com
}

\begin{abstract}
Music is a multidiscipline coordination of human mental physical action. Playing music will cause a variety of physiological reactions in the body. Systems in the human body run by the rhythms of the body regularly and follow a certain pattern so every sound and rhythm of the music to be heard by the human ear can affect the function of the physical anatomy of the body itself. Playing music including physical activity a person so when playing music will work a lot more heart and pulse rate will be fast. The pulse is the body's physiological variables that describe the body in a state of static and dinamis. The pulse needs to know because it describes a person's health condition, if it is too high or low may indicate a health problem. The study is based on observational cross sectional study design. The research sample is a music player with criteria were 30 people aged 11-30 years inclusive, playing music for 30 minutes while the study without stopping, and physically and mentally healthy. The results showed that after playing average music pulse on the subject of men and women has increased. Pulse frequency after playing a musical instrument drum for 30 minutes without stopping more increased than other music devices.
\end{abstract}

Keywords: Playing music, Pulse

\begin{abstract}
Abstrak: Musik merupakan multidisiplin ilmu yang mengkoordinasi aksi fisik-mental manusia. Bermain musik akan menyebabkan berbagai reaksi fisiologis dalam tubuh. Sistem dalam tubuh manusia dijalankan oleh irama tubuh yang teratur dan mengikuti pola tertentu sehingga setiap bunyi dan irama musik yang didengar oleh telinga jasmani manusia dapat mempengaruhi fungsi anatomi tubuh itu sendiri. Bermain musik termasuk aktivitas fisik seseorang sehingga pada saat bermain musik jantung akan bekerja lebih banyak dan denyut nadi akan semain cepat. Denyut nadi merupakan variabel fisiologis tubuh yang menggambarkan tubuh dalam keadaan statis dan dinamis. Denyut nadi perlu diketahui karena menggambarkan kondisi kesehatan seseorang, jika terlalu tinggi atau rendah dapat menunjukkan adanya masalah kesehatan. Penelitian ini berdasarkan observasional dengan rancangan cross sectional study. Sampel penelitian adalah pemain musik berjumlah 30 orang dengan kriteria inklusi berumur 11-30 tahun, bermain musik selama 30 menit saat penelitian tanpa berhenti, dan sehat jasmani dan rohani. Hasil penelitian menunjukkan setelah bermain musik rata-rata denyut nadi pada subjek laik-laki maupun perempuan mengalami peningkatan. Frekuensi denyut nadi setelah memainkan alat musik drum selama 30 menit tanpa berhenti lebih meningkat daripada alat musik lain.
\end{abstract}

Kata kunci: Bermain musik, Denyut nadi 
Saat ini masyarakat global sudah menganggap musik sebagai aspek yang sangat penting dan tidak terpisahkan dalam kehidupan. Hal ini dapat terlihat dari menjamurnya sekolah-sekolah musik, komunitas-komunitas pencinta musik, berbagai event, konser dan workshop dari berbagai kalangan dan genre. ${ }^{1}$

Musik sebagai kebutuhan sekunder dari sisi hiburan telah melekat dengan keseharian manusia, sebagai contoh bermain musik. Setiap orang memiliki musik favorit dan terpukau dengan efek yang ditimbulkannya. ${ }^{2}$ Musik dapat menenangkan, mengangkat spirit kita, membuat sedih, atau memompa tekad dalam menjawab tantangan dan permasalahan dalam kehidupan. Dengan mengetahui jenis-jenis musik dan merasakan efek-efek musik tertentu dalam tubuh, maka kita akan dapat secara efektif memilih alat musik pada saat kita membutuhkannya. ${ }^{3}$

Sistem dalam tubuh manusia sesungguhnya dijalankan oleh suatu irama tubuh yang teratur dan mengikuti pola tertentu. Sebagai contoh irama denyut jantung dan nadi, aliran nafas, langkah kaki, kedipan mata, cara bicara dan bahasa. Semua ini merupakan irama musik alamiah sehingga setiap bunyi-bunyian atau irama musik yang didengar oleh telinga jasmani manusia dapat mempengaruhi fungsi anatomi dari tubuh itu sendiri. ${ }^{4}$

Denyut nadi merupakan salah satu variabel fisiologis tubuh yang menggambarkan tubuh dalam keadaan statis dan dinamis. Oleh karena itu denyut nadi dipakai sebagai indikator metabolisme tubuh. ${ }^{5}$ Dalam bermain musik denyut nadi perlu diketahui karena menunjukkan kondisi kesehatan seseorang. Setiap orang memiliki perbedaan denyut nadi dan ada faktorfaktor yang mempengaruhinya. Denyut nadi yang terlalu tinggi atau terlalu rendah bisa menunjukkan adanya masalah kesehatan. ${ }^{6}$

Pada jantung normal manusia, tiap-tiap denyut berasal dari nodus SA ( irama sinus normal, NSR= Normal Sinus Rhythim). Waktu istirahat jantung berdenyut kira-kira 70 kali kecepatannya, berkurang waktu tidur dan bertambah karena emosi, kerja, demam, dan banyak rangsangan lainnya. ${ }^{7}$ Pada saat beristirahat atau tidak sedang beraktifitas tinggi seperti bekerja atau sedang berolahraga, denyut nadi orang dewasa 6080 kali permenit, anak-anak 80-100 kali permenit, dan bayi 100-140 kali permenit. ${ }^{6}$

Bila memeriksa denyut nadi perhatikanlah kecepatan, irama, dan volumenya. Hitung denyut nadi dalam semenit penuh. ${ }^{8}$ Sudah merupakan kebiasaan umum berbicara tentang kekuatan denyut nadi, yang sebagian besar tergantung atas kekuatan sistolik dan karena jelas bahwa denyut nadi tidak mungkin kuat kalau sistolik ventrikel lemah, atau kalau pengisian ventrikel tidak sempurna. Denyut nadi dapat menjadi lemah walaupun kontraksi jantung sangan kuat. Keadaan ini dijumpai pada beberapa ketidakaturan jantung tertentu. Oleh karena itu, kekuatan denyut nadi bukan merupakan petunjuk yang tepat tentang kekuatan kontraksi jantung. ${ }^{9}$

Denyut nadi bisa menjadi cepat karena bermacam-macam sebab, tapi jarang sekali ada penyebab yang bisa menurunkan denyut nadi. Ketegangan emosi, kelelahan, kurang tidur, dan sebab lain dapat mempercepat denyut nadi sehingga harus berhati-hati mengatakan denyut nadi yang cepat sebagai keadaan yang tidak normal. ${ }^{10}$

Pengaruh musik bagi tubuh yaitu musik mengurangi ketegangan otot dan memperbaiki gerak serta koordinasi tubuh, musik mempengaruhi suhu badan, musik dapat mengatur hormon-hormon yang berkaitan dengan stres, musik dapat memperkuat ingatan dan pelajaran, musik meningkatkan asmara dan seksualitas, serta musik dapat merangsang pencernaan. ${ }^{2}$

\section{METODE PENELITIAN}

Penelitian ini berdasarkan observasional dengan rancangan cross sectional study. Penelitian ini bertujuan untuk mengetahui gambaran denyut nadi pada pemain musik sebelum dan sesudah latihan dengan jenis alat musik yang berbeda di Toms Yamaha Music School Manado.

Sampel dari penelitian ini adalah pemain musik dengan jumlah 30 orang 
yang memenuhi kriteria inklusi berumur 11-30 tahun, bermain musik selama 30 menit saat penelitian tanpa berhenti, dan sehat jasmani dan rohani. Instrumen penelitian yang digunakan adalah alat pengukur denyut nadi digital merek Polygreen dan alat tulis menulis. Adapun variabel pada penelitian ini yaitu pemain musik dan denyut nadi dengan analisis data yang dipakai adalah tabulasi data dan distribusi frekuensi dalam bentuk presentase.

\section{HASIL PENELITIAN}

Penelitian ini merupakan penelitian observasional dengan menggunakan rancangan cross sectional study yang dilakukan sejak bulan November-Desember 2012 di Toms Yamaha Music School Manado.

Subjek penelitian berjumlah 30 orang terdiri atas 18 orang laki-laki dan 12 orang perempuan. Subjek bermain alat musik dengan lima jenis alat musik yang berbeda dan dimainkan masing-masing dalam 30 menit. Sebelum dan sesudah memainkan alat musik dilakukan pengukuran denyut nadi.

\section{Distribusi responden}

Pada Tabel 1 dapat dilihat bahwa jumlah responden terbanyak yang ikut serta dalam penelitian ini berada pada umur antara 11-14 tahun dan 15-18 tahun yaitu masing-masing sebanyak 9 orang atau sekitar 29,97\% dari total jumlah responden yang ada, sedangkan jumlah responden tersedikit berada pada umur antara 23-26 tahun yaitu sebanyak 1 orang atau sekitar 3,33\% dari total jumlah responden.

Pada Tabel 2 dapat dilihat bahwa jumlah responden terbanyak adalah yang memainkan alat musik piano yaitu sebanyak 9 orang atau sekitar 29,97\% yang terdiri atas 3 orang laki-laki dan 6 orang perempuan, sedangkan jumlah responden tersedikit adalah yang memainkan alat musik biola yaitu sebanyak 4 orang perempuan atau sekitar 13,32\% dari total jumlah responden yang ada.

Pada Tabel 3 dapat dilihat bahwa jumlah responden laki-laki dengan umur antara 11-14 tahun, 15-18 tahun, 19-22 tahun, 23-26 tahun, dan 27-30 tahun memiliki rata-rata denyut nadi sebelum bermain musik berturut-turut yaitu 79x/menit, $75 \mathrm{x} /$ menit, $82 \mathrm{x} /$ menit, 86 $\mathrm{x} /$ menit, dan $77 \mathrm{x} /$ menit sedangkan untuk rata-rata denyut nadi sesudah bermain musik yaitu $89 \mathrm{x} /$ menit, $84 \mathrm{x} / \mathrm{menit}$, 100x/menit, $89 \mathrm{x} /$ menit, dan $87 \mathrm{x} /$ menit. Pada sebelum dan sesudah bermain musik terjadi peningkatan denyut nadi dan masih termasuk sebagai denyut nadi normal serta diklasifikasikan sebagai beban aktifitas rendah.

Tabel 1. Distribusi Responden berdasarkan umur dan jenis kelamin

\begin{tabular}{cccccccc}
\hline \multirow{2}{*}{ Umur (tahun) } & \multicolumn{9}{c}{ Jenis Kelamin } & \multicolumn{2}{c}{ Total } \\
\cline { 2 - 5 } & \multicolumn{2}{c}{ Laki-laki } & \multicolumn{2}{c}{ Perempuan } & & \\
\hline & $\mathrm{n}$ & $\%$ & $\mathrm{n}$ & $\%$ & $\mathrm{~N}$ & $\%$ \\
$11-14$ & 5 & 16,65 & 4 & 13,32 & 9 & 29,97 \\
$15-18$ & 3 & 9,99 & 6 & 19,98 & 9 & 29,97 \\
$19-22$ & 4 & 13,32 & 2 & 6,66 & 6 & 19,98 \\
$23-26$ & 1 & 3,33 & 0 & 0 & 1 & 3,33 \\
$27-30$ & 5 & 16,65 & 0 & 0 & 5 & 16,65 \\
TOTAL & 18 & 59,94 & 12 & 39,96 & 30 & 100 \\
\hline
\end{tabular}


Tabel 2. Distribusi Responden berdasarkan jenis alat musik dan jenis kelamin

\begin{tabular}{lcccccc}
\hline \multirow{2}{*}{$\begin{array}{c}\text { Jenis Alat } \\
\text { Musik }\end{array}$} & \multicolumn{5}{c}{ Jenis Kelamin } & \multicolumn{2}{c}{ Total } \\
\cline { 2 - 5 } \multicolumn{1}{c}{ Laki-laki } & \multicolumn{2}{c}{ Perempuan } & & \\
\hline Gitar & $\mathrm{N}$ & $\%$ & $\mathrm{n}$ & $\%$ & $\mathrm{~N}$ & $\%$ \\
Piano & 6 & 19,98 & 0 & 0 & 6 & 19,98 \\
Keyboard & 3 & 9,99 & 6 & 19,98 & 9 & 29,97 \\
Biola & 3 & 9,99 & 2 & 6,66 & 5 & 16,65 \\
Drum & 0 & 0 & 4 & 13,32 & 4 & 13,32 \\
TOTAL & 6 & 19,98 & 0 & 0 & 6 & 19,98 \\
\hline
\end{tabular}

Tabel 3. Rata-rata denyut nadi berdasarkan umur pada responden laki-laki

\begin{tabular}{cccc}
\hline Umur (tahun) & $\begin{array}{c}\text { Jumlah } \\
\text { Responden }\end{array}$ & $\begin{array}{c}\text { Nadi Sebelum } \\
\text { (x/menit) }\end{array}$ & $\begin{array}{c}\text { Nadi Sesudah } \\
\text { (x/menit) }\end{array}$ \\
\hline $11-14$ & 5 & 79 & 89 \\
$15-18$ & 3 & 75 & 84 \\
$19-22$ & 4 & 82 & 100 \\
$23-26$ & 1 & 86 & 89 \\
$27-30$ & 5 & 77 & 87 \\
TOTAL & 18 & & \\
\hline
\end{tabular}

Tabel 4. Rata-rata denyut nadi berdasarkan umur pada responden perempuan

\begin{tabular}{cccc}
\hline Umur (tahun) & $\begin{array}{c}\text { Jumlah } \\
\text { Responden }\end{array}$ & $\begin{array}{c}\text { Nadi Sebelum } \\
\text { (x/menit) }\end{array}$ & $\begin{array}{c}\text { Nadi Sesudah } \\
\text { (x/menit) }\end{array}$ \\
\hline $11-14$ & 4 & 75 & 84 \\
$15-18$ & 6 & 73 & 79 \\
$19-22$ & 2 & 70 & 74 \\
$23-26$ & 0 & 0 & 0 \\
$27-30$ & 0 & 0 & 0 \\
TOTAL & 12 & & \\
\hline
\end{tabular}

Pada Tabel 4 dapat dilihat bahwa jumlah responden perempuan dengan umur antara 11-14 tahun, 15-18 tahun, dan 19-22 tahun memiliki rata-rata denyut nadi sebelum bermain musik berturut-turut yaitu $79 \mathrm{x} /$ menit, $73 \mathrm{x} /$ menit, dan $70 \mathrm{x} /$ menit sedangkan untuk rata-rata denyut nadi sesudah bermain musik yaitu $84 x /$ menit, 79 $\mathrm{x} / \mathrm{menit}$, dan $74 \mathrm{x} /$ menit. Pada sebelum dan sesudah bermain musik terjadi sedikit peningkatan denyut nadi dan masih termasuk sebagai denyut nadi normal serta diklasifikasikan sebagai beban aktifitas rendah, sedangkan pada umur antara 23-26 
Tabel 5. Rata-rata denyut nadi berdasarkan Jenis Alat Musik

\begin{tabular}{lcccc}
\hline \multirow{2}{*}{$\begin{array}{c}\text { Jenis Alat } \\
\text { Musik }\end{array}$} & \multicolumn{2}{c}{ Laki-laki } & \multicolumn{2}{c}{ Perempuan } \\
\cline { 2 - 5 } & $\begin{array}{c}\text { DN Sebelum } \\
\text { (x/menit) }\end{array}$ & $\begin{array}{c}\text { DN Sesudah } \\
\text { (x/menit) }\end{array}$ & $\begin{array}{c}\text { DN Sebelum } \\
\text { (x/menit) }\end{array}$ & $\begin{array}{c}\text { DN Sesudah } \\
(\mathrm{x} / \text { menit })\end{array}$ \\
\hline Gitar & 83 & 86 & 0 & 0 \\
Piano & 83 & 97 & 71 & 82 \\
Keyboard & 76 & 82 & 79 & 83 \\
Biola & 0 & 0 & 73 & 79 \\
Drum & 75 & 95 & 0 & 0 \\
\hline
\end{tabular}

tahun dan 27-30 tahun jumlah respondennya tidak ada.

Dari hasil penelitian yang dilakukan, maka didapatkan bahwa responden lakilaki yang memainkan alat musik gitar, piano, keyboard, dan drum memiliki ratarata denyut nadi sebelum bermain musik berturut-turut yaitu $83 \mathrm{x} / \mathrm{menit}$, 83x/menit, $76 \mathrm{x} /$ menit, dan $75 \mathrm{x} /$ menit sedangkan untuk rata-rata denyut nadi sesudah bermain musik berturut-turut yaitu $86 \mathrm{x} /$ menit, 97 x/menit, $82 \mathrm{x} /$ menit, dan $95 \mathrm{x} /$ menit. Terjadi peningkatan denyut nadi antara sebelum dan sesudah bermain musik dan peningkatan terbanyak pada alat musik drum.

Pada responden perempuan yang memainkan alat musik piano, keyboard, dan biola mamiliki rata-rata denyut nadi sebelum bermain musik berturut-turut yaitu 71 $\mathrm{x} /$ menit, $79 \mathrm{x} /$ menit, dan $73 \mathrm{x} /$ menit sedangkan untuk rata-rata denyut nadi sesudah bermain musik berturut-turut yaitu $82 \mathrm{x} /$ menit, $83 \mathrm{x} / \mathrm{menit}$, dan 76x/menit. Terjadi peningkatan denyut nadi antara sebelum dan sesudah bermain musik dan peningkatan terbanyak pada alat musik piano.

\section{BAHASAN}

Berdasarkan hasil penelitian yang diperoleh, didapati bahwa terjadi peningkatan rata-rata denyut nadi sesudah bermain musik.

Hal ini karena denyut nadi yang diukur setelah bermain musik merupakan denyut nadi sesaat. Denyut nadi tersebut dalam waktu sekitar 30 menit akan mengalami penurunan kembali sebagai hasil adaptasi tubuh. Denyut nadi merupakan tanda langsung tekanan darah dan detak jantung yang dikendalikan oleh sistem saraf otonom, yaitu saraf simpatik dan saraf parasimpatik. ${ }^{10}$ Pada tabel 3, 4, dan 5 dapat dilihat bahwa ada sedikit perbedaan denyut antara laki-laki dan perempuan.

Berdasarkan hasil penelitian yang diperoleh, yang membedakan denyut nadi berbeda tiap-tiap subjek penelitian salah satunya adalah usia. Subjek penelitian yang ikut serta pada penelitian ini berusia antara 11 - 30 tahun. Pada tabel 3 dan 4 dapat dilihat bahwa terjadi peningkatan denyut nadi pada semua subjek setelah memainkan alat musik. Frekuensi nadi secara bertahap akan menetap memenuhi kebutuhan oksigen selama pertumbuhan. Pada masa remaja, denyut jantung menetap dan iramanya teratur.

Pada Tabel 3 dan 4 dapat dilihat perbedaan peningkatan denyut nadi antara laki-laki dan perempuan. Setelah pubertas, rata-rata frekuensi denyut nadi laki-laki sedikit lebih rendah daripada perempuan. Adapun faktor lain yang mempengaruhi denyut nadi yaitu ukuran tubuh. Semakin berat atau gemuk seseorang denyut nadinya akan lebih cepat. ${ }^{7,11}$ Pada subjek penelitian ada beberapa responden laki-laki yang berbadan gemuk sehingga denyut nadi responden laki-laki sedikit lebih tinggi daripada perempuan.

Berdasarkan sebuah jurnal Frontiers in Human Neuroscience yang melibatkan 70 
orang musisi dan bukan musisi ditemukan bahwa belajar alat musik dan terus memainkannya berpengaruh pada mental sehingga menjadi positif sepanjang aktivitasnya. Penelitian ini dilakukan oleh Brenda Hanna-Pladdy dari Emory University di Atlanta, Amerika Serikat. Disamping itu, kebiasaan bermain musik terbukti memberi manfaat positif bagi pendengaran. Jika seseorang belajar musik dari kecil hingga dewasa, maka ia memiliki memori dan kemampuan kognitif yang lebih baik, dan apabila hal ini tetap bertahan hingga usia lanjut maka kemampuan berpikir akan tetap baik. ${ }^{12}$

Berdasarkan hasil penelitian yang didapat, memainkan alat musik dapat menyebabkan peningkatan denyut nadi. Kenaikan frekuensi denyut nadi akan sesuai dengan intensitas latihan. Semakin tinggi intensitas subjek bermain musik maka denyut nadi akan terasa semakin cepat. Denyut nadi yang meningkat pada saat setelah latihan diakibatkan kebutuhan penyediaan darah yang lebih banyak pada waktu latihan. Saat beristirahat jantung berdenyut kira-kira 70 kali, kecepatannya berkurang waktu tidur dan bertambah karena emosi, demam, beraktifitas, dan banyak rangsangan yang lainnya. Denyut nadi para pemain musik akan terus meningkat bila suhu tubuh meningkat. Denyut nadi maksimum untuk orang dewasa adalah 180-200 denyut per menit dan keadaan ini biasanya hanya dapat berlangsung dalam waktu beberapa menit saja. $^{7}$

Pada jurnal ilmiah Nature menyimpulkan bahwa mempelajari alat musik dapat meningkatkan prestasi akademik subjek. Hal ini berasal dari fakta bahwa bermain musik menggunakan kedua sisi rasional (otak kiri) dan sisi kreatif (otak kanan) sehingga dapat meningkatkan IQ. Para subjek yang memainkan alat musik dapat membuat kemampuan otak mereka berkembang. Sebuah penelitian di AS menunjukkan bahwa memainkan alat musik dapat membalikkan beberapa komponen stress. $^{13}$
Bermain musik akan menyebabkan perubahan-perubahan pada faal tubuh subjek, baik bersifat sementara (respon) maupun bersifat menetap (adaptasi). ${ }^{14}$ Bermain musik akan mengeluarkan energi yang berhubungan erat dengan konsumsi energi. Konsumsi energi pada saat bermain musik biasanya ditentukan secara tidak langsung, yaitu dengan pengukuran kecepatan denyut jantung dan konsumsi oksigen. Kecepatan denyut jantung memiliki hubungan yang sangat erat dengan aktifitas faal lainnya, seperti tekanan darah, aliran darah, komposisi kimia dalam darah, temperatur tubuh, tingkat penguapan, dan jumlah udara yang dikeluarkan oleh paru-paru.

Astrand \& Rodahl (1997); Rodahl (1989) menyatakan bahwa denyut nadi mempunyai hubungan linier yang tinggi dengan asupan oksigen pada saat beraktifitas. Salah satu cara yang sederhana untuk menghitung denyut nadi adalah dengan merasakan denyutan pada arteri radialis di pergelangan tangan subjek. ${ }^{15}$

\section{SIMPULAN}

Berdasarkan penelitian yang telah dilakukan maka diperoleh kesimpulan bahwa frekuensi denyut nadi setelah memainkan alat musik secara teratur mengalami peningkatan dan denyut nadi pemain musik drum lebih meningkat daripada denyut nadi alat musik lain.

\section{SARAN}

Apabila pemain musik merasa tertekan atau stress sebelum latihan musik ataupun sehabis latihan fisik/olahraga, sebaiknya perlu istirahat sejenak sambil mendengarkan musik karena dapat membantu pikiran menjadi rileks. Khususnya bagi pemain musik drum, perlu diperhatikan denyut nadi sebelum latihan. Hal ini untuk mencegah terjadinya peningkatan denyut nadi yang berlebihan setelah latihan. 


\section{UCAPAN TERIMA KASIH}

Ucapan terima kasih disampaikan pada dr. D. H. C. Pangemanan, MKes, AIFM sebagai penguji 1 , dr. H. Polii, MKes, AIFM sebagai penguji 2, dan pada semua pihak yang baik secara langsung maupun tidak langsung telah menumbuhkan ide atau gagasan dalam pemikiran penulis sehingga dapat menyelesaikan artikel ini.

\section{DAFTAR PUSTAKA}

1. Kementerian Pendidikan Nasional. 2009. Musik. Direktorat Jenderal Pendidikan Non Formal dan Informal, Direktorat Pembinaan Kursus dan Kelembagaan.

2. Campbell, D.G. 2002. Efek mozart: tapping the power of music to heal the body, strengthen the mind, and unlock the creative spirit. Penerbit PT Gramedia Pustaka Utama: hal 84-97.

3. Manz, C.C. 2007. Emotional discipline: langkah pengubah hidup untuk merasa lebih baik setiap hari. Penerbit PT Gramedia Pustaka Utama: hal 157.

4. Ucup, M. 2010. Musik sebagai terapi. Diakses 18 Oktober 2012. Available from: http://m.artikel.sabda.org/node/473

5. Azizah, N.I. 2008. Hubungan denyut nadi dengan kelelahan kerja. Diakses 18 Oktober 2012. Available from: http://www.fkm.undip.ac.id/data/index.php ?action $=4 \& i d x=2417$

6. Yukez. 2012. Denyut nadi. Diakses 18 Oktober 2012. Available from: http://yukez.wordpress.com/2012/04/10/de nyut-nadi/
7. K.A. Siswantiningsih. 2010. Perbedaan denyut nadi sebelum dan sesudah bekerja pada iklim kerja panas di unit workshop PT. indo acidatama Tbk kemiri, kebakkramat, karanganyar. Skripsi pada Fakultas Kedokteran universitas Sebelas Maret, Surakarta.

8. Burnside, J.W., Thomas. J. McGlynn. 1995. Adams diagnosis fisik. Penerbit Buku Kedokteran EGC: hal 70-72.

9. Delf, M.H., Robert Manning. 1996. Major diagnosis fisik. Penerbit Buku Kedokteran EGC: hal 281-286.

10. Wibowo, D.S. 2008. Anatomi tubuh manusia. Penerbit PT Grasindo: hal 59.

11. Berman, A., Shirlee Snyder, Barbara Kozier, Glenora Erb. 2009. Buku ajar praktik keperawatan klinis. Penerbit Buku Kedokteran EGC: hal 21-32.

12. Brenda, H., Pladdy. 2010. Frontiers in Human Neuroscience. Diakses 20 Januari 2013. Available from: http://m.liputan6.com/read/427976/bisamain-musik-bikin-otak-tetap-encer

13. Jurnal Ilmiah Nature dipublikasikan oleh Nature Publishing Group (Britania Raya). 2011. Diakses 21 Januari 2013. Available from: http://m.forum.detik.com/main-alatmusik-tingkatkan-iq-anakt257533.html?1993306frm\&amp;langid=1

14. Ronny, Setiawan, Fatimah, S. 2008. Fisiologi kardiovaskular. Penerbit Buku Kedokteran EGC: hal 54.

15. Kusmindari, D., Pasmawati, Y. 2011. Pengaruh musik terhadap beban kerja fisik karyawan di bagian produksi. Vol 8, no 2: hal 5. Diakses 15 November 2012. 